EESTI NSV TEADUSTE AKADEEMIA TOIMETISED. 28. KOIDE KEEMIA. 1979, NR. 4

ИЗВЕСТИЯ АКАДЕМИИ НАУК ЭСТОНСКОИ ССР. ТОМ 28 Химия. 1979, № 4

УдК $547.466 .1 ; 547.725 ; 547.156 .2$

Марет ПАНК, О. КИРРЕТ

\title{
СИНТЕ3 N-3-(2-ФУРИЛ)-АКРИЛОИЛПЕПТИДОВ
}

Maret PANK, O. KIRRET, N-3-(2-FUROOL)-AKROLOUOLPEPTIIDIDE SUNTEES

Maret PANK, O. KIRRET. SYNTHESIS OF N-3-(2-FURYL)-ACRYLOYLPEPTIDES

N-3-(2-фурил) -акрилоиловые пептиды представляют интерес в качестве субстратов протеолитических ферментов, прежде всего термолизина и других нейтральных металлоэндопептидаз [']. Преимущество субстратов этого типа состоит в том, что наличие вблизи расщепляемой пептидной связи остатка 3-(2-фурил)-акриловой кислоты, обладающего характерным ультрафиолетовым спектром, позволяет следить за ходом ферментативной реакции спектрофотометрически.

Целью нашей работы был синтез ряда фурилакрилоиловых пептидов для изучения субстратной специфичности нейтральных металлопротеаз, продуцируемых термофильным актиномицетом Thermoactinomyces vulgaris.

Известно, что специфичность металлоэндопептидаз термолизинового типа определяется прежде всего природой аминокислотного остатка, которому принадлежит аминная группа расщепляемой пептидной связи. Поэтому для нас представляло интерес синтезировать ряд пептидов с общей формулой

$$
\begin{aligned}
& \text { - } \mathrm{CH}=\mathrm{CH}-\mathrm{C}-\mathrm{NH}-\mathrm{CH}_{2}-\underset{\mathrm{II}}{\mathrm{C}}-\mathrm{NH}-\stackrel{\mathrm{C}}{*} \mathrm{H}-\mathrm{C}=\mathrm{O} \\
& \mathrm{R}_{1} R_{2} \\
& (\downarrow-\text { указывает на расщепляемую связь, } \\
& *-\text { оптически активная аминокислота.) }
\end{aligned}
$$

В этих пептидах первая аминокислота (глицин) была одинаковой для всех членов ряда, а вторая аминокислота менялась.

Таким образом, надо было синтезировать общую для всех пептидов часть -N-3-(2-фурил) -акрилоилглицин и найти подходящий метод конденсации со второй половиной молекулы - аминокислотами, их эфирами, амидами или дипептидами. 


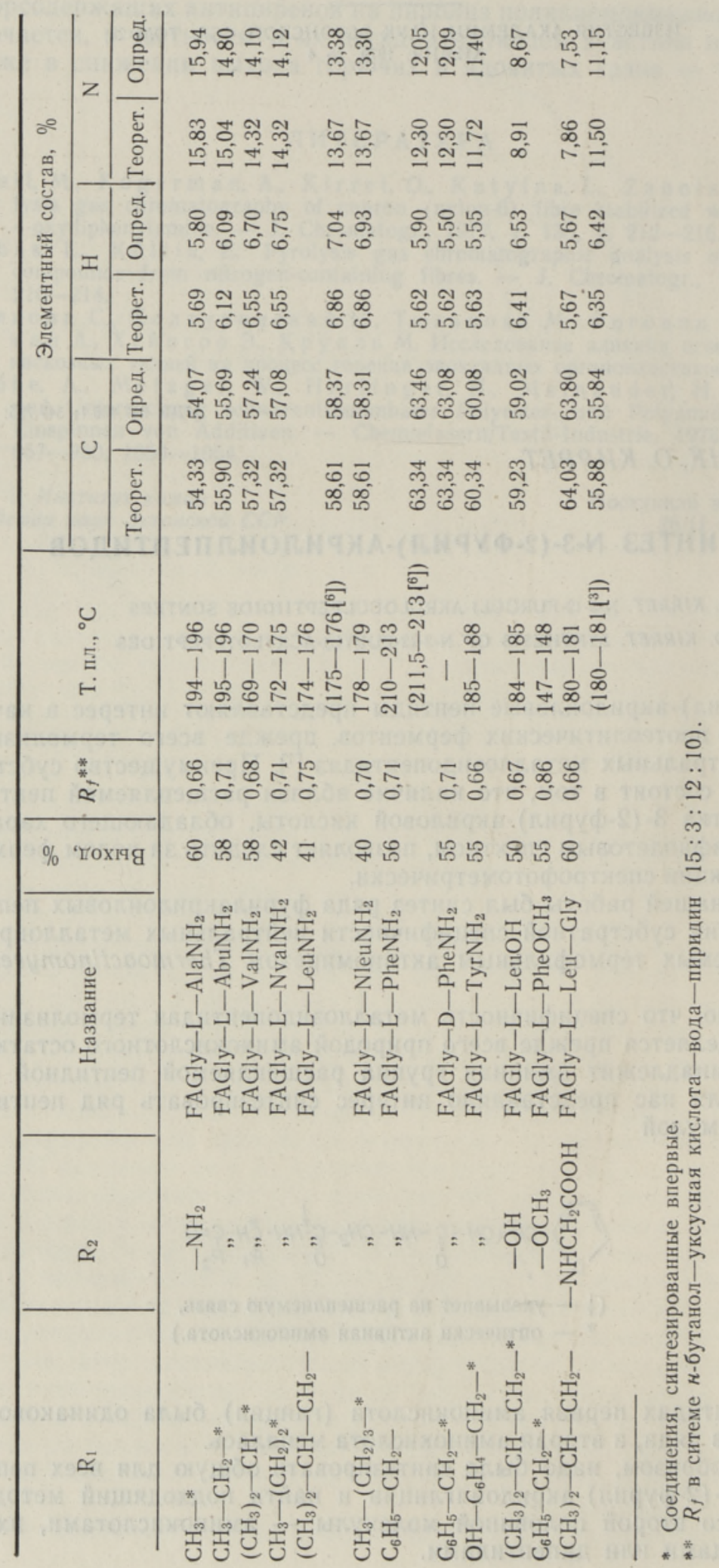


Нами была сделана попытка провести прямую конденсацию двух частей молекулы субстрата при помощи $\mathrm{N}, \mathrm{N}^{\prime}$-дициклогексилкарбодиимида. Однако, несмотря на неоднократное варьирование условий реакции, нами была получена ацилмочевина, которая часто является побочным продуктом при этой реакции $\left[{ }^{2}\right]$.

Сравнительно недавно был описан [3] синтез некоторых фурилакрилоиловых пептидов методом активированных $\mathrm{N}$-оксисукцинимидных эфиров. Предложенная в [3] методика была с успехом использована и в настоящей работе. $\mathrm{N}$-оксисукцинимидный эфир N-3-(2-фурил)-акрилоилглицина, полученный при помощи $\mathrm{N}, \mathrm{N}^{\prime}$-дициклогексилкарбодиимида, вводили в реакцию конденсации с соответствующим аминокомпонентом и получали нужный фурилакрилоиловый пептид с выходом $40-60 \%$.

Соединения, полученные по этой методике конденсации, перечислены в таблице.

Предварительное изучение показало, что большинство из синтезированных соединений действительно являются субстратами нейтральной металлопротеазы Thermoactinomyces vulgaris штамм 42, причем скорость гидролиза зависит от гидрофобности остатка [ $\left.{ }^{4}\right]$.

Общая схема синтеза следующая:

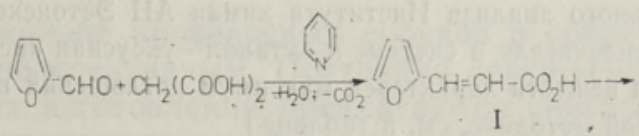

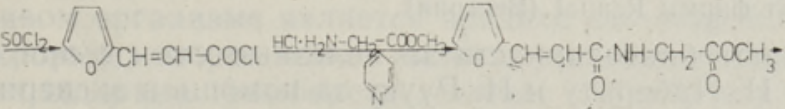

$$
\begin{aligned}
& \text { II III } \\
& \longrightarrow \mathrm{KOH}_{0} \mathrm{CH}=\mathrm{CH}+\mathrm{C}-\mathrm{NH}-\mathrm{CH}_{2} \mathrm{C}-\mathrm{OH}+\left.\right|_{\mathrm{O}} ^{\mathrm{CH}_{2}-\mathrm{C}=\mathrm{O}} \mathrm{N}_{2}-\mathrm{OH}=\mathrm{OH} \\
& \text { V V VI } \quad \text { VI }
\end{aligned}
$$

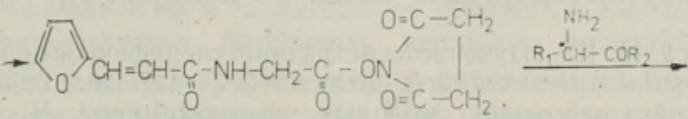

$$
\begin{aligned}
& \text { VIII } \\
& \text { IX } \\
& \rightarrow-2 \mathrm{CH}=\mathrm{CH}-\mathrm{C}-\mathrm{NH}-\mathrm{CH}_{2}-\mathrm{C}-\mathrm{NH}-\underset{\mathrm{C}}{\mathrm{C}} \mathrm{C}-\mathrm{R}_{1}-\mathrm{COR}_{2} \\
& \mathrm{X}
\end{aligned}
$$

\section{Экспериментальная часть}

3-(2-Фурил)-акриловая кислота (1) была синтезирована из фурфурола и малоновой кислоты по известной методике [5].

Хлорангидрид 3-(2-фурил)-акриловой кислоты (II) синтезирован при помоши хлористого тионила по методике $\left.{ }^{6}\right]$. 
Хлоргидраты метиловых эфиров аминокислот (III) синтезированы пропусканием сухого хлористого водорода через суспензию соответствующей амннокислоты в метаноле [7].

Хлоргидраты амидов аминокислот (IX) получены обработкой хлоргидратов эфиров аминокислот насыщенным при $0{ }^{\circ} \mathrm{C}$ метанольным раствором аммиака [7]. Если полученные хлоргидраты амидов содержали хлористый аммоний, то их переводили в свободные амиды обработкой насыщенным при $-5^{\circ}$ раствором аммиака в хлороформе, отделяли хлористый аммоний фильтрованием и отгоняли растворитель на роторном испарителе. 3-(2-Фурил)-акрилоилглицин (V) получен из хлорангидрида 3-(2-фурил)-акрнловов̆ кислоты и хлоргидрата метилового эфира глицина с последующим омылением [ $\left.{ }^{6}\right]$.

$\mathrm{N}$-Гидроксисукцинимид (VI) получен по методике $\left[{ }^{8}\right]$ из ангидрида янтарной кислоты и гидрохлорида гидроксиламина.

N,N'-дициклогексилкарбодиимид (VII) препарат фирмы Fluka A. G. (Швейцария).

$\mathrm{N}$-оксисукцинимидный эфир 3-(2-фурил)-акрилоилглицина (VIII) получен при помощи $\mathrm{N}, \mathrm{N}^{\prime}$-дициклогексилкарбодиимида из 3-(2-фурил) -акрилоилглицина и $\mathrm{N}$-гидроксисукцинимида по методике [3].

3-(2-Фурил)-акрилоиловые дипептиды, их эфиры, амиды или трипептиды (X) получены по общей методике $\left.{ }^{3}\right]$ из $\mathrm{N}$-оксисукцинимидного эфира 3-(2-фурил)-акрилоилглицина и соответствующего аминокомпонента. Продукты реакции очищали переосаждением из этанола эфиром или водой. Выходы 40-60\%. Чистоту полученных веществ проверяли элементарным анализом (анализ был проведен на анализаторе фирмы Hewlett-Packard в секторе инструментального анализа Института химии АН Эстонской ССР) и хроматографией в тонком слое силикагеля в системе $\boldsymbol{H}$-бутанол-уксусная кислота-вода-пиридин $(15: 3: 12: 10)$. Для веществ характерен максимум поглощения при 302 нм. (Соединения, полученные по этой методике, см. в таблице.)

L-Leu-Gly препарат фирмы Reanal (Венгрия).

Авторы выражают благодарность за полезные советы при выполнении данной работы Н. Пабериту и И. Руусу за помощь в экспериментальной работе.

\section{ЛИТЕРАТУ РА}

1. Feder, J. A spectrophotometric assay for neutral protease. - Biochem. Biophys. Res. Communs, 1968 , v. $32, \mathrm{~N} 2$, p. $326-332$.

2. Ш реде р Э., Л юб ке К. Пептиды. Т. 1. М., 1967, с. 156-158.

3. Blumberg, S., Vallee, B. Superactivation of thermolysin by acrylation with amino acid N-hydroxysuccinimide esters. - Biochemistry, 1975, v. 14, N 11, p. $2410-2419$.

4. Пан к М. С., Фин к Н. Ю. Изучение суб́тратной специфичности нейтральной протеазы Thermoactinomyces vulgaris штамм 42. - В кн.: Тезисы докладов II Республиканской конференции молодых ученых-химиков. Ч. І. Таллин, 1977, c. $116-117$.

5. Organic syntheses. An annual publication of satisfactory methods for the preparation of organic chemicals (New York), 1945, v. 25, p. 51.

6. Feder, J., Schuck, J. M. Studies on the Bacillus subtilis neutral-protease and Bacillus thermoproteolyticus thermolysin - catalyzed hydrolysis of dipeptide substrates. - Biochemistry, 1970, v. 9, N 14, p. 2784-2791.

7. Г ринш тей н Дж., В ин и д $М$. Химия аминокислот и пептидов. М., 1965.

8. Anderson, G. W., Z immerman, J. E., Callah a n, F. M. The use of esters of N-hydroxysuccinimide in peptide synthesis. - J. Amer. Chem. Soc., 1964, v. 86, p. $1839-1842$.

Институт химии

Академии наук Эстонской ССР
Поступила в редакцию 6/IV 1979 